\title{
Developing a Soil Physical Quality Index (SPQi) for lowlands under different deployment
}

\section{times of no-tillage}

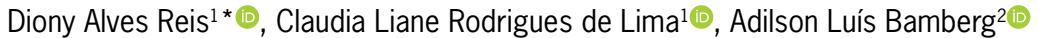

\author{
${ }^{1}$ Universidade Federal de Pelotas/FAEM - Depto. de Solos, \\ Campus Universitário s/n - 96050-500 - Pelotas, RS - \\ Brasil. \\ Embrapa Clima Temperado, Rod. BR 392, km 78 - 96010- \\ 971 - Pelotas, RS - Brasil. \\ *Corresponding author <dionyodin@gmail.com>
}

Edited by: Silvia del Carmen Imhoff

Received May 30, 2017

Accepted October 05, 2017

\begin{abstract}
Soil physical quality in lowlands from the Pampa biome under no-tillage (NT) plays an important role; therefore, this study aimed to establish a soil physical quality index (SPQi) from a minimum data set to detect the effects of different deployment times of NT in an Albaqualf. The comparison of areas with one (NT1), three (NT3), five (NT5) and seven (NT7) years of notillage was established using as reference a non-cultivated field plot (NC) for at least thirty years, nearby the sites under NT. Soil samples with undisturbed and disturbed structure were collected to determine the physical quality indicators and soil organic matter (SOM) fractions. The factor analysis (FA) was used to identify and select a minimum data set. The SPQi was elaborated by using the deviations of the measured indicators at different deployment times of NT in relation to NC. The SPQi showed sensibility to identify and explain soil physical quality changes with different deployment times of NT. In well-drained lands, higher deployment times of no-tillage promote the physical quality of lowlands.
\end{abstract}

Keywords: factor analysis, minimum data set, management systems, lowland soils

\section{Introduction}

In Brazil, the Pampa biome occurs in Rio Grande do Sul State (RS), where 5.4 million hectares are lowlands, and Albaqualf is the predominant class (Parfitt et al., 2014). Albaqualf has high agricultural and economic importance due to its physical characteristics. The presence of a subsurface layer almost impermeable, with expansive clays and low macro/microporosity ratio, favor irrigated rice and livestock. Thus, the agricultural growth of the region is strongly dependent on understanding soil physical properties in this environment.

Rainfed crops have been recently introduced into these soils, mostly cultivated under conventional tillage (CT) (Reis et al., 2016). The soybean has been an alternative for the traditional flooded rice-livestock sequence, but there is a concern with the sustainability of this production model, as no-tillage (NT) has proven more profitable and environmentally favorable in rainfed agriculture (Crittenden et al., 2015; Fernández-Romero et al., 2016; Raiesi and Kabiri, 2016) than other management systems.

Impacts of management systems on soil physical quality (SPQ) have been studied by the S index (Dexter, 2004), but its inconsistency has also been highlighted (van Lier, 2014; Moncada et al., 2015). In this sense, soil quality indices (SQI) were developed based on the appropriate selection of soil quality indicators to compose a minimum data set (MDS) (Karlen and Stott, 1994; Karlen et al., 2001; Lima et al., 2008; Maia, 2013; Chen et al., 2013; Yao et al., 2013; Zornoza et al., 2015; Zhang et al., 2016; Rojas et al., 2016).

In MDS, attributes can be chosen by statistical methods (Paz-Kagan et al., 2014; Raiesi and Kabiri, 2016; Obade and Lal, 2016), such as the factor analysis (FA), which reduces redundant information from the original data set and groups soil attributes highly interrelated in a smaller group of representative and independent attributes (Zhang et al., 2016; Raiesi and Kabiri, 2016), helping to understand the effects of changing from CT to the NT system on soil physical quality.

Thus, given the agricultural importance of lowlands from the Pampa biome, this study aimed to establish an MDS to develop a soil physical quality index (SPQi) and evaluate its sensitivity to different deployment times of NT in Albaqualf from southern Brazil.

\section{Materials and Methods}

The study was carried out at the Lowland Experimental Station - Embrapa Temperate Agriculture, located in Capão do Leão, RS, Brazil (31 $49^{\prime} 04.13^{\prime \prime}$ S, $52^{\circ} 27^{\prime} 53.77^{\prime \prime} \mathrm{W}, 14 \mathrm{~m}$ above sea level). The climate is $C f a$, according to Köppen classification (Alvares et al., 2013), a hot mesothermal climate, with average temperature of coldest month between 3 and $18{ }^{\circ} \mathrm{C}$. Average monthly rainfall is not below $60 \mathrm{~mm}$, always humid, and average temperature of the hottest month higher than $22^{\circ} \mathrm{C}$. The soil was classified as Albaqualf (NRCS, 2010) with $460 \mathrm{~g} \mathrm{~kg}^{-1}$ of sand, $370 \mathrm{~g} \mathrm{~kg}^{-1}$ of silt and $170 \mathrm{~g} \mathrm{~kg}^{-1}$ of clay within 0.0 to $0.2 \mathrm{~m}$ top layer.

The surface soil layer of the experimental area was historically managed under conventional tillage (CT). For this study, four experimental plots were selected and homogenized before NT deployment through chisel plowing and soil acidity correction by superficial incorporation of dolomitic limestone using disc harrows. Then, different cover crops (Table 1) were established posteriorly, using 2 $\mathrm{kg} \mathrm{N} \mathrm{ha}{ }^{-1}, 26.2 \mathrm{~kg} \mathrm{P} \mathrm{ha}^{-1}$ and $49.8 \mathrm{~kg} \mathrm{ha}^{-1}$ of mineral fertilizer to summer crops and $15 \mathrm{~kg} \mathrm{~N} \mathrm{ha}^{-1}, 26.2 \mathrm{~kg} \mathrm{P} \mathrm{ha}^{-1}$, $49.8 \mathrm{~kg} \mathrm{ha}^{-1}$ (base fertilization) and $100 \mathrm{~kg} \mathrm{~N} \mathrm{ha}^{-1}$ (cover fertilization) to summer and winter grasses. Furthermore, spontaneous plants were not fertilized. 
Table 1 - Crop sequence cultivated in an Albaqualf under different deployment times of no-tillage (NT).

\begin{tabular}{lclllll}
\hline Deployment times of NT & \multicolumn{7}{c}{ Growing season } \\
\cline { 2 - 7 } & $2007 / 08$ & $2008 / 09$ & $2009 / 10$ & $2010 / 11$ & $2011 / 12$ & $2012 / 13$ \\
\hline NT1 & $\ldots$ & $\ldots$ & $\ldots$ & $\ldots$ & $M a$ & Wh $+\mathrm{Ma}$ \\
NT3 & $\ldots$ & $\ldots$ & $\mathrm{Mi}$ & $\mathrm{Rg}+\mathrm{Sp}+\mathrm{Sb}$ & $\mathrm{Wh}+\mathrm{Sb}$ & $\mathrm{Wh}+\mathrm{Sb}$ \\
NT5 & $\mathrm{Ma}$ & $\mathrm{Rg}+\mathrm{Sp}+\mathrm{Sb}$ & $\mathrm{Wh}+\mathrm{Sg}$ & $\mathrm{Rg}+\mathrm{Sp}+\mathrm{Sb}$ & $\mathrm{Wh}+\mathrm{Sb}$ & $\mathrm{Rg}+\mathrm{Sp}+\mathrm{Sb}$ \\
NT7 & $\mathrm{Ma}$ & $\mathrm{Wh}+\mathrm{Sf}$ & $\mathrm{Wh}+\mathrm{Ma}$ & $\mathrm{Rg}+\mathrm{Sp}+\mathrm{Sg}$ & $\mathrm{Rg}+\mathrm{Sp}+\mathrm{Sb}$ & $\mathrm{Rg}+\mathrm{Sp}+\mathrm{Sb}$ \\
\hline
\end{tabular}

${ }^{*}$ NT1: one; NT3: three; NT5: five and NT7: seven years of no-tillage (NT) deployment, respectively. Ma = mayze (Zea mays L.); Wh = Wheat (Triticum aestivum); Rg = ryegrass (Lolium multiflorum); $\mathrm{Sp}=$ plants of spontaneous development; $\mathrm{Sb}=$ soybean (Glycine max); $\mathrm{Sg}=$ sorghum (Sorghum bicolor); $\mathrm{Sf}=$ sunflower (Helianthus anuus).

The study consists of five treatments, four NT [one (NT1), three (NT3), five (NT5) and seven (NT7) years under no-till] and a control treatment consisting of a 30-yr non-cultivated $(\mathrm{NC})$ field located near the no-till treatments.

Soil samples with disturbed and undisturbed structure were collected from the 0.00 to $0.03 ; 0.03$ to $0.06 ; 0.06$ to 0.10 and 0.10 to $0.20 \mathrm{~m}$ soil layers. The sampled layers were defined in terms of their susceptibility to physical and hydric changes that originated from tillage and root systems activity of cultivated crops over the time.

Soil samples with undisturbed structure were collected with steel cylinders of $0.05 \mathrm{~m}$ diameter and $0.03 \mathrm{~m}$ height, totaling 240 samples (three cylinders for each layer $\times$ four soil layers $\times$ four replicates $\times$ five treatments). The soil samples were used to determine total porosity (TP), macroporosity $(\mathrm{Ma})$, microporosity (Mi) $(0.006 \mathrm{MPa}$ to distinguish $\mathrm{Ma}$ and $\mathrm{Mi}$ by the tension table method), soil penetration resistance (PR) (Rousseau et al., 2013; D'Hose et al., 2014), bulk density (Bd) (Merrill et al., 2013) and soil compressive parameters, preconsolidation pressure $(\sigma \mathrm{p})$, bulk density at preconsolidation pressure $(\mathrm{Bd} \sigma \mathrm{p})$, compression index (CI) (Krümmelbein et al., 2010), degree of compactness (Kondo and Dias Junior, 1999), at $\sigma \mathrm{p}$ (DC $\sigma \mathrm{p}, \%$ ) and at $1.600 \mathrm{kPa}$ (DC1.600) (Reichert et al., 2016).

Soil samples with disturbed structure were collected, totaling 80 samples (one soil sample $\times$ four soil layers $\times$ four replicates $\times$ five treatments), to determine size classes of water-stable aggregates $\mathrm{C} i$, where $i$ represents $1,2,3,4,5$ classes $\mid \mathrm{C} 1=9.51$ to $4.76 \mathrm{~mm}$; $\mathrm{C} 2=4.75$ a $2.00 \mathrm{~mm} ; \mathrm{C} 3=1.99$ a $1.00 \mathrm{~mm} ; \mathrm{C} 4=0.99$ a $0.50 \mathrm{~mm}$; $\mathrm{C} 5=0.49$ a $0.25 \mathrm{~mm}$ and $\mathrm{C} 6<0.25 \mathrm{~mm}$ ), Macroaggregates (Macro), Microaggregates (Micro), mean weight diameter of aggregates (MWD) (Kemper and Rosenau, 1986; Palmeira et al., 1999; Yoder, 1936), the free light fraction (FLF), the occluded light fraction (OLF) and the heavy fraction (HF) of organic matter contained in soil aggregates by performing the densimetric fractionation of soil organic matter (SOM) (Imaz et al., 2010).

The total organic carbon content (TOC) was determined (dry combustion - Perkin Elmer elemental analyzer) in the densimetric fractions, and the carbon pool index (CPI), the carbon lability index (CLI) and the carbon management index (CMI) were quantified.
The dataset included 24 indicators: TP, Ma, Mi, PR, Bd, op, CI, Bdøp, DC $\sigma \mathrm{p}, \mathrm{DC} 1600, \mathrm{C} 2, \mathrm{C} 3, \mathrm{C} 4, \mathrm{C} 5$, Macroaggregates, Microaggregates, MWD, FLF, OLF, HF, TOC, CPI, CLI and CMI. The soil attributes were subjected to the factor analysis (FA) to identify highly correlated indicators for subsequent establishment of a minimum data set by eliminating attributes considered as redundant.

The FA was carried out using covariance (raw data) and correlation (standardized data) matrix. Variables with sampling adequacy (Kaiser Criterion) $<0.5$ were eliminated from the FA. Using the correlation matrix, factors with eigenvalues $>1$ were retained and subjected to varimax rotation to maximize correlation between factors and measured attributes and to constitute the minimum data set (Yao et al., 2013; Mueller et al., 2013; Mota et al., 2014). The FA, the Communality and the SPQi were performed by PROC FACTOR and PROC ANOVA in SAS (Statistical Analyses System Institute, version 9.2).

The Measure of Sampling Adequacy (MSA) indicates the proportion of variance in the variables caused by underlying factors. Values close to 1.0 (the measures can range from 0 to 1) generally indicate that the FA may be useful with the data while values lower than 0.5 indicate that the FA is probably not be suitable (Beavers et al., 2013).

Equation 1 was used to calculate the MSA value:

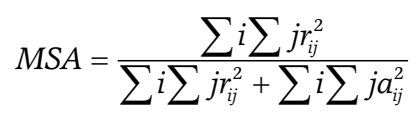

MSA represents the ratio of the squared correlation between variables to the squared partial correlation between variables (Kaiser, 1974), where: $r_{i j}$ is the correlation coefficient observed between variables $i$ and $j$; $a_{i j}$ is the partial correlation coefficient between the same variables that is, simultaneously, an estimate of the correlation between the factors. The $\alpha_{i j}$ is probably close to zero because factors are orthogonal to each other.

The deviations of the measured attribute values in the areas under different deployment times of NT in relation to the reference values measured in the non-cultivated field $(\mathrm{NC})$ were calculated according to equation 2 :

$z_{i}=\frac{x-\bar{x}}{s}$ 
where: $z_{i}$ is the standardized value selected by the FA with mean $(\mu)$ and standard deviation $(\sigma)$ equals to zero and one, respectively; $x$ is the value of the soil attribute evaluated in the sites with different deployment times of NT; $\bar{x}$ and $s$ is the mean and the standard deviation, respectively, of the soil attribute evaluated in NC.

To estimate the values of quality index $\left(Q I_{i}\right)$ of the each evaluated soil attribute, we used equations 3, 4 and 5 for the conditions "more is better", "less is better" and "midpoint optimum", respectively, with $\beta=\exp$ (1,7145zi) (Maia, 2013).

The curve for the condition "more is better" has positive derivative and is used in indicators that improve soil quality, for example, total porosity, total organic carbon, etc.; "midpoint optimum" has positive derivative until a maximum value and is used in indicators that positively affect soil quality until certain values that, if passed, cause negative influence such as bulk density, penetration resistance, etc. The curve for the condition "less is better" has negative derivative and is used in indicators that negatively affect the soil quality index, such as compactness degree (Chen et al., 2013; Nakajima et al., 2015; Zhang et al., 2016).

$$
\begin{aligned}
& Q I=\frac{1}{1+\beta} \\
& Q I=\frac{\beta}{1+\beta} \\
& Q I=\frac{4 \beta}{(1+\beta)^{2}}
\end{aligned}
$$

The soil physical quality index (SPQi) in each evaluated site was calculated by equation 6 :

$$
S P Q i=\frac{\sum_{i=n}^{n} Q I_{i}}{n}
$$

where: $Q I_{i}$ is the quality index of the evaluated characteristic and $n$ is the number of evaluated characteristics. Soil quality evaluated with $Q I_{i}$, for the conditions "more is better", "less is better" and "midpoint optimum" and without changes compared to the reference site has $Q I_{i}$ equal to one. Thus, values farther from one mean higher changes in relation to $\mathrm{NC}$ and reflecting these changes in SPQi (Maia, 2013; Chen et al., 2013; Nakajima et al., 2015; Zhang et al., 2016).

\section{Results and Discussion}

The analysis of 24 soil quality indicators of Albaqualf resulted in significant correlation $(p<0.05)$ in 172 of 276 soil attribute pairs (Table 2). Highest positive correlation coefficients $(\mathrm{r} \geq 0.80)$ were obtained for TP $\times \mathrm{Mi}, \mathrm{FLF} \times \mathrm{TOC}, \mathrm{HF} \times \mathrm{TOC}, \mathrm{HF} \times \mathrm{CPI}, \mathrm{C} 3 \times \mathrm{C} 4$, CLI $\times$ CMI, while the highest negative correlation was observed between Macro and Micro ( $\mathrm{r}=0.97)$. The carbon content in OLF showed negative correlation with
PR $(r>0.60)$, suggesting that compaction reduces the carbon content between and within aggregates and favors the soil degradation process. In contrast, the TOC presented positive correlation with $\mathrm{Ma}(\mathrm{r}=0.77)$.

Askari and Holden (2015) evaluated 22 indicators of soil physical quality for assessing the effects of management practices on SQ in temperate maritime soils, while Yao et al. (2013) used the Factor analysis (FA) to group 22 variables. According to Armenise et al. (2013), the FA general rules is to receive high eigenvalues (> $1.00)$ and to select variables with high factor loadings. These components allow to obtain the best parameter representative and retain it for screening of MDS /Chen et al., 2013; Yao et al., 2013; Zornoza et al., 2015; Zhang et al., 2016; Rojas et al., 2016).

The MSA values are used to keep or exclude attributes from the FA and are given in Table 3. Only 15 from the 24 soil attributes used initially were kept after the Kaiser criterion (MSA > 0.5). Despite the MSA values below 0.5, the following variables DC $\sigma \mathrm{p}, \mathrm{DC} 1.600$, CPI and CLI were kept because the mean MSA value obtained for the set of variables was higher than 0.5 . The FA was performed using a group of attributes with mean MSA higher than 0.5 thus using the parameters: $\mathrm{TP}, \mathrm{Ma}, \mathrm{Bd}, \mathrm{PR}, \mathrm{FLF}$, OLF, TOC, $\sigma \mathrm{p}, \mathrm{CI}, \mathrm{Bd} \sigma \mathrm{p}, \mathrm{DC} \sigma \mathrm{p}$, DC1600, CPI, CLI and CMI similarly to Yao et al. (2013) and Beniston et al. (2016).

Eigenvalues from the correlation matrix indicate that the first four factors explained $>98 \%$ of total data variation (Table 4) (Yao et al., 2013; Paz-Kagan et al., 2014; Beniston et al., 2016; Basak et al., 2016).

Factors with eigenvalue below 1 explain less variance than an isolated soil attribute and therefore were refused according to the Kaiser Criterion (Armenise et al., 2013; Thomazini et al., 2015). The first factor, with eigenvalue $>5$, explained $53 \%$ of total data variance (Table 4) with FLF and TOC, evidencing the higher positive loadings (0.93 and 0.92, respectively). Nevertheless, contrasted with $\mathrm{Bd}$ and $\mathrm{PR}$, that showed greater negative loadings (-0.63 and -0.61, respectively) (Table 5). Similarly, the second factor with an eigenvalue higher than one represents $17 \%$ of total variability, where CLI and CMI evidenced higher positive loadings (0.80 and 0.76), contrasting with $\mathrm{TP}, \mathrm{OLF}$ and $\mathrm{CI}$, which showed greater negative loadings $(-0.24,-0.24$ and -0.21 , respectively) (Table 5).

Considering the magnitude of the factorial loadings of soil attributes presented in each factor, authors have named factors according to the relationship between soil attributes and factors (Karlen et al., 2013; Gong et al., 2015). For example, factor 1 could be named as "Organic factor" because it presents positive factor loadings $>0.9$, and the highest factor loadings were observed with attributes FLF and TOC. However, the factors were not named in this study.

Greater communality estimates were observed in CLI and CMI (0.98) (Table 5), evidencing that these attributes share variability (Yao et al., 2013; Mueller et al., 2013), as well as TOC (0.97) and FLF (0.89). Fur- 


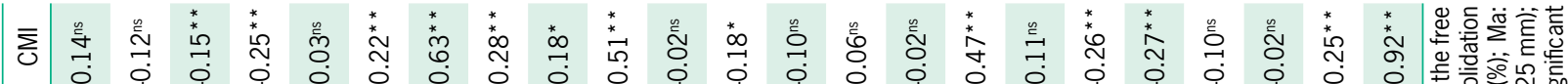
J

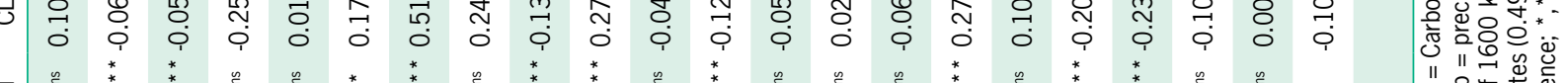

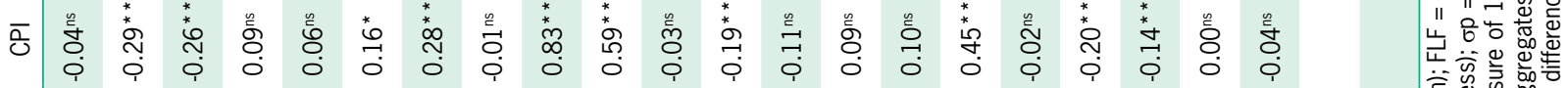

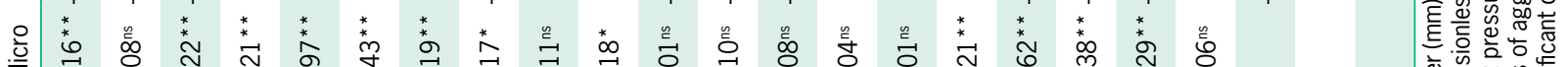

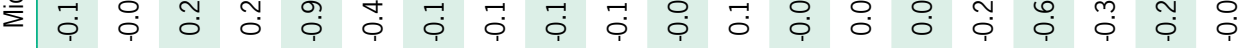

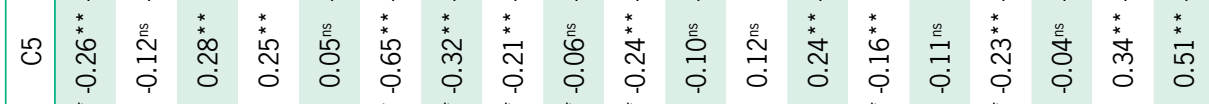

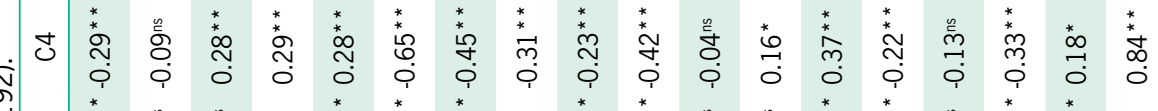

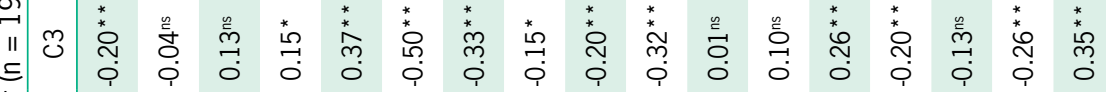
离

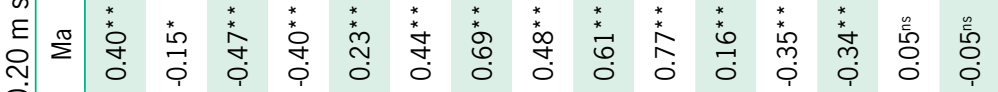

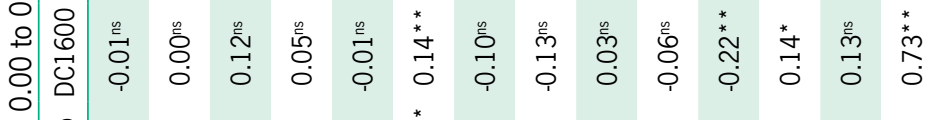
芯

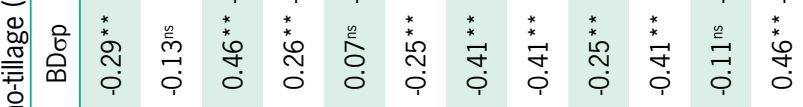

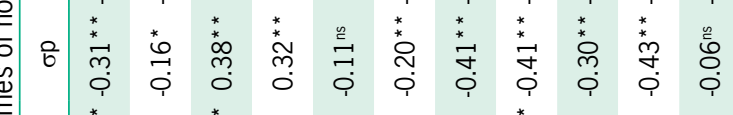

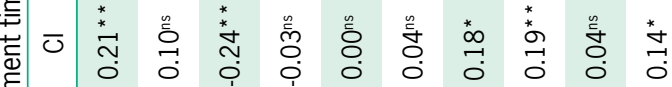

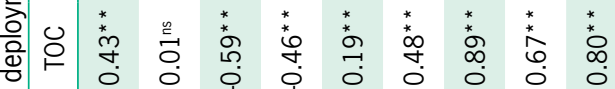

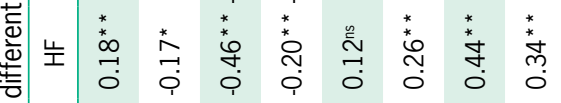

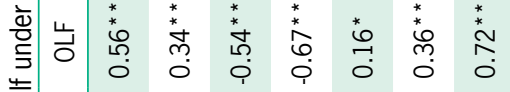

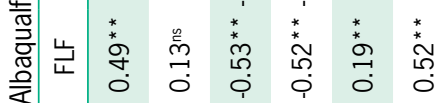

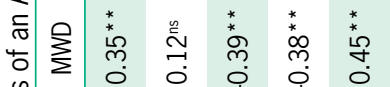

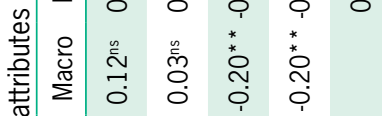

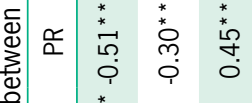

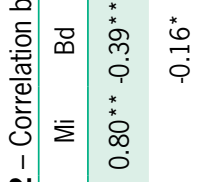

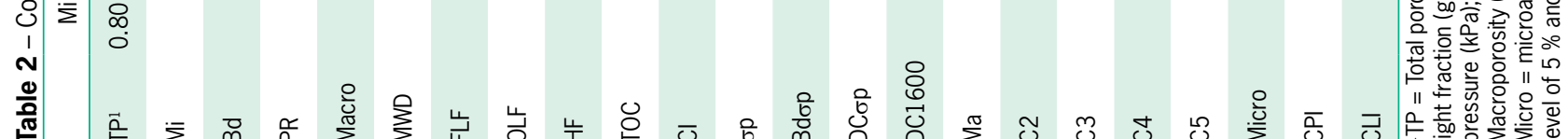


Table 3 - Kaiser-Meyer-Olkin Measure of Sampling Adequacy (MSA) of attributes of an Albaqualf under different deployment times of no-tillage (NT) in 0.00 to $0.20 \mathrm{~m}$ soil layer.

\begin{tabular}{|c|c|}
\hline Attributes & MSA \\
\hline $\mathrm{TP}^{1}$ & 0.88 \\
\hline $\mathrm{Bd}$ & 0.91 \\
\hline PR & 0.88 \\
\hline FLF & 0.80 \\
\hline OLF & 0.85 \\
\hline TOC & 0.73 \\
\hline $\mathrm{Cl}$ & 0.69 \\
\hline$\sigma p$ & 0.80 \\
\hline BDøp & 0.85 \\
\hline DCop & 0.48 \\
\hline DC1600 & 0.49 \\
\hline $\mathrm{Ma}$ & 0.90 \\
\hline $\mathrm{CPI}$ & 0.33 \\
\hline CLI & 0.48 \\
\hline $\mathrm{CMI}$ & 0.57 \\
\hline Mean MSA value & 0.71 \\
\hline \multicolumn{2}{|c|}{ 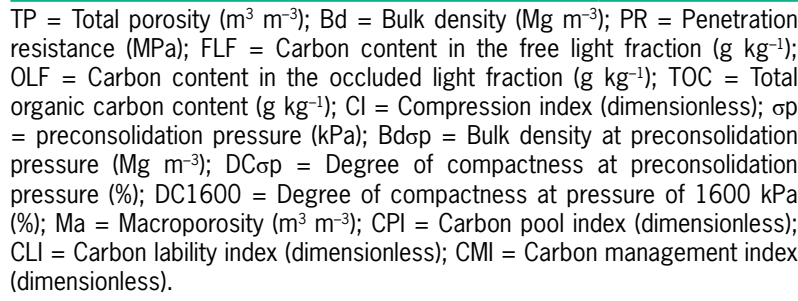 } \\
\hline
\end{tabular}

Table 4 - Eigenvalue, difference, proportion and cumulative variance explained by factor analysis using correlation matrix (standardized data) for 0.00 to $0.20 \mathrm{~m}$ soil layer of an Albaqualf under different deployment times of no-tillage (NT).

\begin{tabular}{lcccc}
\hline Factors & Eigenvalue & Difference & Proportion & Cumulative \\
\hline 1 & & & & $\%$ \\
2 & 5.21 & 3.53 & 0.53 & 53 \\
3 & 1.68 & 0.19 & 0.17 & 70 \\
4 & 1.49 & 0.27 & 0.15 & 86 \\
5 & 1.22 & 0.84 & 0.12 & 98 \\
6 & 0.38 & 0.16 & 0.04 & 100 \\
7 & 0.22 & 0.08 & 0.02 & 100 \\
8 & 0.13 & 0.07 & 0.01 & 100 \\
9 & 0.06 & 0.05 & 0.01 & 100 \\
10 & 0.01 & 0.03 & 0.00 & 100 \\
11 & -0.02 & 0.01 & 0.00 & 100 \\
12 & -0.02 & 0.03 & 0.00 & 100 \\
13 & -0.06 & 0.06 & -0.01 & 100 \\
14 & -0.12 & 0.05 & -0.01 & 100 \\
15 & -0.16 & 0.06 & -0.02 & 100 \\
\hline & -0.17 & 0.06 & -0.02 & 100 \\
\hline
\end{tabular}

thermore, high values of communality estimate suggest that a high part of variance was explained by the factor. Lower values of communality estimate means no correlation or low correlation, as observed in CI. Thus, CI was the least important attribute due to the lowest communality estimate.
Table 5 - Proportion of variance using varimax rotation and communality estimates for soil attributes in the 0.00 to $0.20 \mathrm{~m}$ soil layer of an Albaqualf under different deployment times of notillage.

\begin{tabular}{lccccc}
\hline Attributes & Factor 1 & Factor 2 & Factor 3 & Factor 4 & Communality estimates \\
\hline FLF $^{1}$ & 0.93 & 0.09 & -0.04 & 0.01 & 0.89 \\
TOC & 0.92 & -0.06 & 0.20 & 0.24 & 0.97 \\
OLF & 0.77 & -0.24 & -0.17 & -0.27 & 0.77 \\
Ma & 0.75 & -0.01 & 0.14 & 0.18 & 0.62 \\
TP & 0.55 & -0.24 & -0.06 & -0.28 & 0.45 \\
BD $\sigma p$ & -0.49 & 0.26 & -0.03 & 0.06 & 0.45 \\
op & -0.51 & 0.18 & -0.03 & 0.03 & 0.42 \\
PR & -0.61 & 0.14 & 0.14 & 0.34 & 0.55 \\
BD & -0.63 & 0.32 & -0.02 & -0.02 & 0.51 \\
CLI & 0.47 & 0.80 & -0.30 & -0.13 & 0.98 \\
CMI & 0.61 & 0.76 & -0.08 & 0.09 & 0.98 \\
Cl & 0.18 & -0.21 & -0.19 & 0.08 & 0.12 \\
DC1600 & -0.11 & 0.19 & 0.69 & -0.41 & 0.70 \\
DC $\sigma p$ & 0.08 & 0.12 & 0.65 & -0.47 & 0.68 \\
CPI & 0.34 & 0.02 & 0.59 & 0.66 & 0.89 \\
\hline
\end{tabular}

${ }^{1} \mathrm{FLF}=$ Carbon content in the free light fraction $\left(\mathrm{g} \mathrm{kg}^{-1}\right)$; TOC = Total organic carbon content $\left(\mathrm{g} \mathrm{kg}^{-1}\right)$; OLF $=$ Carbon content in the occluded light fraction $\left(\mathrm{g} \mathrm{kg}^{-1}\right) ; \mathrm{Ma}=$ Macroporosity $\left(\mathrm{m}^{3} \mathrm{~m}^{-3}\right) ; \mathrm{TP}=$ Total porosity $\left(\mathrm{m}^{3} \mathrm{~m}^{-3}\right) ; \mathrm{Bd} \sigma \mathrm{p}$ $=$ Bulk density at preconsolidation pressure $\left(\mathrm{Mg} \mathrm{m}^{-3}\right) ; \sigma \mathrm{p}=$ preconsolidation pressure $(\mathrm{kPa}) ; \mathrm{PR}=$ Penetration resistance $(\mathrm{MPa}) ; \mathrm{Bd}=$ Bulk density $\left(\mathrm{Mg} \mathrm{m}^{-3}\right)$; $\mathrm{CLI}=$ Carbon lability index (dimensionless); $\mathrm{CMI}=$ Carbon management index (dimensionless); $\mathrm{Cl}=$ Compression index (dimensionless); $\mathrm{DC1600}=$ Degree of compactness at pressure of $1600 \mathrm{kPa}(\%)$; DC $\sigma \mathrm{p}=$ Degree of compactness at preconsolidation pressure (\%); CPI = Carbon pool index (dimensionless).

The rotation of factors was applied to minimize the number of attributes with high factorial loadings within the same factor. Rotation also shows the relation of dependence between each other, negative or positive. High factorial loadings were observed in OLF (0.81), FLF (0.68), TP (0.64), Bd (-0.51) and PR (-0.71) in Factor 1 , despite the positive and negative loadings. Therefore, the dependence between them was evident, as seen in their correlation coefficients (Table 2), suggesting that choosing one is enough to represent Factor 1 and the variables that compose it.

CLI and CMI presented positive loadings $>0.9$ in Factor 2 while CPI, TOC and Ma showed positive loadings > 0.5. In Factor 4, DC1.600 and DC $\sigma p$ presented positive loadings $>0.8$ (Table 6).

According to the three standardization models ("less is better", "more is better" and "midpoint optimum"), one parameter was selected per factor to compose the quality index of Albaqualf under different NT deployment times: Factor 1 (PR) "less is better", Factor $3(\mathrm{Ma})$ "midpoint optimum" and Factor 4 (DCop) "less is better". Attributes for Factor 2 were not chosen, because the higher factor loading (>0.9) were observed in CLI and CMI, which are already quality indexes of the Albaqualf compared to NC.

In general, a tendency of quality improvement of Albaqualf was seen with higher deployment times in all evaluated soil layers. This can be observed by greater $\mathrm{Ma}$ and lower PR and DC p values, linked to the higher deployment time of NT (Table 7). Soil quality, evaluated 
through several characteristics that influence plant growth and development and considering the three selected parameters, was promoted by the long term of NT. This is evident because of the high correlation coefficient 10.86 , $p<0.0001$ ) between SPQi and higher deployment times of NT (Figure 1).

Table 6 - Varimax orthogonal rotation of the factors for soil attributes in 0.00 to $0.20 \mathrm{~m}$ soil layer of an Albaqualf under different deployment times of no-tillage.

\begin{tabular}{lcccc}
\hline Atributes & Factor 1 & Factor 2 & Factor 3 & Factor 4 \\
\hline OLF $^{1}$ & 0.81 & 0.14 & 0.05 & -0.08 \\
FLF & 0.68 & 0.46 & 0.38 & -0.07 \\
TP & 0.64 & 0.02 & 0.01 & 0.02 \\
BD & -0.51 & 0.02 & -0.28 & 0.10 \\
PR & -0.70 & -0.15 & 0.05 & -0.01 \\
CLI & 0.13 & 0.98 & -0.08 & 0.00 \\
CMI & 0.15 & 0.94 & 0.27 & 0.03 \\
CPI & -0.11 & 0.00 & 0.93 & 0.08 \\
TOC & 0.61 & 0.25 & 0.68 & -0.04 \\
Ma & 0.48 & 0.25 & 0.53 & -0.04 \\
DC1600 & -0.02 & -0.05 & 0.05 & 0.82 \\
DC $\sigma p$ & 0.07 & 0.00 & 0.02 & 0.81 \\
Cl & 0.21 & -0.07 & 0.03 & -0.25 \\
BD $\sigma p$ & -0.30 & -0.01 & -0.10 & 0.02 \\
$\sigma p$ & -0.28 & -0.08 & -0.14 & 0.02 \\
\hline
\end{tabular}

${ }^{1} \mathrm{OLF}=$ Carbon content in the occluded light fraction $\left(\mathrm{g} \mathrm{kg}^{-1}\right) ; \mathrm{FLF}=$ Carbon content in the free light fraction $\left(\mathrm{g} \mathrm{kg}^{-1}\right) ; \mathrm{TP}=$ Total porosity $\left(\mathrm{m}^{3} \mathrm{~m}^{-3}\right) ; \mathrm{Bd}=$ Bulk density ( $\left.\mathrm{Mg} \mathrm{m}^{-3}\right) ; \mathrm{PR}=$ Penetration resistance (MPa); $\mathrm{CLI}=$ Carbon lability index (dimensionless); $\mathrm{CMI}=$ Carbon management index (dimensionless); CPI $=$ Carbon pool index (dimensionless); TOC $=$ Total organic carbon content ( $\mathrm{g}$ $\left.\mathrm{kg}^{-1}\right) ; \mathrm{Ma}=$ Macroporosity $\left(\mathrm{m}^{3} \mathrm{~m}^{-3}\right) ; \mathrm{DC} 1600=$ Degree of compactness at pressure of $1600 \mathrm{kPa}(\%) ; \mathrm{DC} \sigma \mathrm{p}=$ Degree of compactness at preconsolidation pressure (\%); $\mathrm{Cl}=$ Compression index (dimensionless); $\mathrm{Bd} \sigma \mathrm{p}=$ Bulk density at preconsolidation pressure $\left(\mathrm{Mg} \mathrm{m}^{-3}\right) ; \sigma p=$ preconsolidation pressure $(\mathrm{kPa})$.

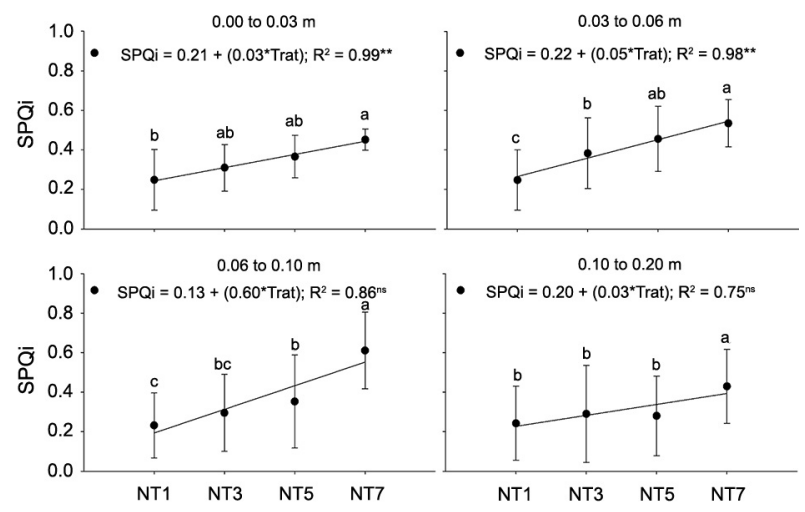

Figure 1 - Soil physical quality index (SPQi) for different layers of an Albaqualf under different deployment times of no-tillage (NT). Vertical bars represent mean standard deviation; ns = nonsignificant difference; ${ }^{*},{ }^{* *}$ significantly different at $5 \%$ and at 1 $\%$, respectively. ${ }^{\star} \mathrm{NT} 1$ : one; NT3: three; NT5: five and NT7: seven years of no-tillage (NT) deployment, respectively. Points followed by the same letter are not significantly different according to Duncan test at $5 \%$, considering each evaluated soil layer.
Table 7 - Mean values, standard deviation (SD) and variation coefficient (VC, \%) Macroporosity (Ma), Penetration resistance (PR) and compactness degree at preconsolidation pressure (DC $\sigma p)$ of an Albaqualf at a non-cultivated field stie and under different deployment times of no-tillage (NT).

\begin{tabular}{|c|c|c|c|}
\hline & $\mathrm{Ma}$ & PR & DC $\sigma \mathrm{p}$ \\
\hline & $\mathrm{m}^{3} \mathrm{~m}^{-3}$ & $\mathrm{MPa}$ & $\%$ \\
\hline & \multicolumn{3}{|c|}{ Non-cultivated field in the 0.00 to $0.03 \mathrm{~m}$} \\
\hline Mean & 9.10 & 0.73 & 91.01 \\
\hline SD & 2.84 & 0.15 & 3.34 \\
\hline \multirow[t]{2}{*}{$\mathrm{VC}$} & 31.24 & 20.26 & 3.66 \\
\hline & \multicolumn{3}{|c|}{ Deployment time of NT } \\
\hline NT1 & 1.44 & 1.12 & 90.45 \\
\hline NT3 & 2.95 & 0.90 & 90.50 \\
\hline NT5 & 4.13 & 0.84 & 92.32 \\
\hline \multirow[t]{2}{*}{ NT7 } & 6.42 & 0.80 & 89.98 \\
\hline & \multicolumn{3}{|c|}{ SPQi } \\
\hline NT1 & 0.04 & 0.16 & 0.55 \\
\hline NT3 & 0.10 & 0.32 & 0.51 \\
\hline NT5 & 0.20 & 0.33 & 0.57 \\
\hline \multirow[t]{2}{*}{ NT7 } & 0.52 & 0.35 & 0.48 \\
\hline & \multicolumn{3}{|c|}{ Non-cultivated field in the 0.03 to $0.06 \mathrm{~m}$} \\
\hline Mean & 8.40 & 0.85 & 90.74 \\
\hline SD & 3.14 & 0.22 & 5.14 \\
\hline \multirow[t]{2}{*}{ VC } & 37.42 & 26.26 & 5.66 \\
\hline & \multicolumn{3}{|c|}{ Deployment time of NT } \\
\hline NT1 & 1.97 & 1.44 & 86.42 \\
\hline NT3 & 3.24 & 1.12 & 91.94 \\
\hline NT5 & 3.91 & 1.03 & 90.95 \\
\hline \multirow[t]{2}{*}{ NT7 } & 6.16 & 0.97 & 88.74 \\
\hline & \multicolumn{3}{|c|}{ SPQi } \\
\hline NT1 & 0.11 & 0.08 & 0.55 \\
\hline NT3 & 0.22 & 0.19 & 0.74 \\
\hline NT5 & 0.31 & 0.27 & 0.78 \\
\hline \multirow[t]{2}{*}{ NT7 } & 0.73 & 0.32 & 0.55 \\
\hline & \multicolumn{3}{|c|}{ Non-cultivated field in the 0.06 to $0.10 \mathrm{~m}$} \\
\hline Mean & 8.34 & 0.89 & 93.43 \\
\hline SD & 3.50 & 0.13 & 5.21 \\
\hline \multirow[t]{2}{*}{$\mathrm{VC}$} & 41.96 & 14.40 & 5.58 \\
\hline & \multicolumn{3}{|c|}{ Deployment time of NT } \\
\hline NT1 & 1.68 & 1.78 & 88.38 \\
\hline NT3 & 1.94 & 1.35 & 88.60 \\
\hline NT5 & 2.23 & 1.30 & 91.48 \\
\hline \multirow[t]{2}{*}{ NT7 } & 7.37 & 1.15 & 91.22 \\
\hline & \multicolumn{3}{|c|}{ SPQi } \\
\hline NT1 & 0.14 & 0.00 & 0.55 \\
\hline NT3 & 0.17 & 0.04 & 0.68 \\
\hline NT5 & 0.19 & 0.05 & 0.82 \\
\hline \multirow[t]{2}{*}{ NT7 } & 0.87 & 0.23 & 0.74 \\
\hline & & ted field & $00.20 \mathrm{~m}$ \\
\hline Mean & 5.49 & 1.03 & 90.14 \\
\hline SD & 1.12 & 0.15 & 4.41 \\
\hline VC & 20.48 & 14.82 & 4.89 \\
\hline & & eployme & \\
\hline NT1 & 2.08 & 2.21 & 90.09 \\
\hline NT3 & 2.10 & 1.72 & 90.92 \\
\hline NT5 & 2.67 & 1.56 & 90.45 \\
\hline NT7 & 3.96 & 1.52 & 91.01 \\
\hline & & & \\
\hline NT1 & 0.12 & 0.00 & 0.61 \\
\hline NT3 & 0.03 & 0.06 & 0.78 \\
\hline NT5 & 0.10 & 0.06 & 0.68 \\
\hline NT7 & 0.51 & 0.07 & 0.71 \\
\hline
\end{tabular}


Considering that a better SPQi is equal to $1, \mathrm{NT} 7$ showed the highest SPQi value (0.61) in 0.06 to 0.10 soil layer. In adjacent layers, the SPQi also increased with higher deployment times of NT; however, it tended to decrease in at 0.10 to $0.20 \mathrm{~m}$ depth. In this study, deviations of attributes were evaluated in relation to $\mathrm{NC}$, which does not necessarily mean that $\mathrm{NC}$ has optimal conditions. Although NC was even not grazed, and remained unmanaged during the last 30 years, NC is representative to a naturally restored area, not a native field.

The SPQi has shown sensitivity and ability to detect changes resulting from soil tillage practices (Figure 1) (Mukherjee and Lal, 2014; Mota et al., 2014; Askari and Holden, 2015; Crittenden et al., 2015; Duval et al., 2016). The evaluated tool has shown that higher deployment time of NT promoted the physical quality of the Albaqualf. Furthermore, the SPQi has shown efficiency to evaluate soil quality. Moreover, it can be used to compare areas subjected to different practices and cultivation conditions.

The physical improvement of lowlands evaluated in this study was demonstrated through several indicators, in particular through that SPQi, which compiled the information of many indicators. The SPQi has shown the ability of NT to ameliorate lowlands for a better adaptation of highland crops in the Pampa biome, as well as to promote soil ecological and conservation functions (i.e. carbon fixation, water infiltration and aeration, drainage regulation and erosion prevention). These benefits are similar to those observed in Brazilian well-drained lands cultivated under NT.

\section{Conclusion}

The present study has demonstrated the efficiency of the factorial analysis in selecting the parameters to constitute a minimum data set to evaluate soil quality under different deployment times of no-till. The soil physical quality index (SPQi), constructed from macroporosity, soil resistance to penetration and the compaction degree in the preconsolidation pressure were sensitive to reflect soil physical quality improvements of Albaqualf. This study has also showed that the improvement of physical quality from a cropped Albaqualf is highly dependent of organic matter accumulation in soil surface layers. No-tillage also generated and preserved roots derived and interaggregate macropores, which are essential for gas diffusion and rapid flow of internal water drainage in these soils. Regardless of inherent differences between soil types, the benefits of no tillage for physical status of the studied Albaqualf were comparable to those in Brazilian Oxisols.

\section{Acknowledgments}

To Coordenação de Aperfeiçoamento de Pessoal de Nivel Superior (CAPES) for a scholarship granted to the first author; to the Federal University of Pelotas and Embrapa Temperate Agriculture for the opportunity, financial and laboratory support and infrastructure.

\section{Authors' Contributions}

Conceptualization: Bamberg, A.L. Data Acquisition: Reis, D.A., Bamberg, A.L. Data Analysis: Reis, D.A. Design of Methodology: Lima, C.L.R. Writing and Editing: Reis, D.A., Lima, C.L.R., Bamberg, A.L.

\section{References}

Alvares, C.A.; Stape, J.L.; Sentelhas, P.C.; Gonçalves, J.L.M.; Sparovek, G. 2013. Köppen's climate classification map for Brazil. Meteorologische Zeitschrift 22: 711-728.

Armenise, E.; Redmile-Gordon, M.A.; Stellacci, A.M.; Ciccarese, A.; Rubino, A.P. 2013. Developing a soil quality index to compare soil fitness for agricultural use under different managements in the Mediterranean environment. Soil and Tillage Research 130: 91-98.

Askari, M.S.; Holden, N.M. 2015. Quantitative soil quality indexing of temperate arable management systems. Soil and Tillage Research 150: 57-67.

Basak, N.; Datta, A.; Mitran, T.; Roy, S.S.; Saha, B.; Biswas, S.; Mandal, B. 2016. Assessing soil-quality indices for subtropical rice-based cropping systems in India. Soil Research 54: 20-29.

Beavers, A.S.; Lounsbury, J.W.; Richards, J.K.; Huck, S.W.; Skolits, G.J.; Esquivel, S.L. 2013. Practical considerations for using exploratory factor analysis in educational research. Practical Assessment, Research and Evaluation 18: 1-13.

Beniston, J.W.; Lal, R.; Mercer, K.L. 2016. Assessing and managing soil quality for urban agriculture in a degraded vacant lot soil. Land Degradation \& Development 27: 996-1006.

Chen, Y.; Wang, H.; Zhou, J.; Xing, L.; Zhu, B.; Zhao, Y.; Chen, X. 2013. Minimum data set for assessing soil quality in farmland of northeast China. Pedosphere 23: 564-576.

Crittenden, S.J.; Poot, N.; Heinen, M.; van Balen, D.J.M.; Pulleman, M.M. 2015. Soil physical quality in contrasting tillage systems in organic and conventional farming. Soil and Tillage Research 154: 136-144.

D'Hose, T.; Cougnon, M.; De Vliegher, A.; Vandecasteele, B.; Viaene, N.; Cornelis, W.; Van Bockstaele, E.; Reheul, D. 2014. The positive relationship between soil quality and crop production: a case study on the effect of farm compost application. Applied Soil Ecology 75: 189-198.

Dexter, A.R. 2004. Soil physical quality. I. Theory, effects of soil texture, density, and organic matter, and effects on root growth. Geoderma 120: 201-214.

Duval, M.E.; Galantini, J.A.; Martínez, J.M.; López, F.M.; Wall, L.G. 2016. Sensitivity of different soil quality indicators to assess sustainable land management: influence of site features and seasonality. Soil and Tillage Research 159: 9-22.

Fernández-Romero, M.L.; Clark, J.M.; Collins, C.D.; ParrasAlcántara, L.; Lozano-García, B. 2016. Evaluation of optical techniques for characterizing soil organic matter quality in agricultural soils. Soil and Tillage Research 155: 450-460.

Gong, L.; Ran, Q.; He, G.; Tiyip, T. 2015. A soil quality assessment under different land use types in Keriya river basin, southern Xinjiang, China. Soil and Tillage Research 146: 223-229. 
Imaz, M.J.; Virto, I.; Bescansa, P.; Enrique, A.; Fernandez-Ugalde, O.; Karlen, D.L. 2010. Soil quality indicator response to tillage and residue management on semi-arid Mediterranean cropland. Soil and Tillage Research 107: 17-25.

Kaiser, H.F. 1974. An index of factorial simplicity. Psychometrika 39: 32-35.

Karlen, D.L.; Andrews, S.S.; Doran, J.W. 2001. Soil quality: current concepts and applications. Advances in Agronomy 74: 1-40.

Karlen, D.L.; Kovar, J.L.; Cambardella, C.A.; Colvin, T.S. 2013. Thirty-year tillage effects on crop yield and soil fertility indicators. Soil and Tillage Research 130: 24-41.

Karlen, D.L.; Stott, D.E. 1994. A framework for evaluating physical and chemical indicators of soil quality. p. 53-72. In: Doran, J.W.; Coleman, D.C.; Bezdicek, D.F.; Stewart, B.A., eds. Defining soil quality for a sustainable environment. Soil Science Society of America, Madison, WI, USA. (SSSA Special Publication, 35).

Kemper, W.D.; Rosenau, R.C. 1986. Aggregate stability and size distribution. p. 425-441. In: Klute, A., ed. Methods of soil analysis. 2ed. Soil Science Society of America, Madison, WI, USA.

Kondo, M.K.; Dias Junior, M.S. 1999. Management and moisture effects on the compressive behavior of three latosols (oxisols). Brazilian Journal of Soil Science 23: 497-506 (in Portuguese, with abstract in English).

Krümmelbein, J.; Horn, R.; Raab, T.; Bens, O.; Hüttl, R.F. 2010. Soil physical parameters of a recently established agricultural recultivation site after brown coal mining in eastern Germany. Soil and Tillage Research 111: 19-25.

Lima, A.C.R.; Hoogmoed, W.B.; Brussaard, L. 2008. Soil quality assessment in rice production systems: establishing a minimum data set. Journal of Environmental Quality 37: 623-630.

Maia, C.E. 2013. Environmental quality in soil with different growing season cultivated $\mathrm{w}$ ith muskmelon irrigated. Ciência Rural 43: 603-609 (in Portuguese, with abstract in English).

Merrill, S.D.; Liebig, M.A.; Tanaka, D.L.; Krupinsky, J.M.; Hanson, J.D. 2013. Comparison of soil quality and productivity at two sites differing in profile structure and topsoil properties. Agriculture, Ecosystems and Environment 179: 53-61.

Moncada, M.P.; Ball, B.C.; Gabriels, D.; Lobo, D. 2015. Evaluation of soil physical quality index $S$ for some tropical and temperate medium-textured soils. Soil Science Society of America Journal 79: 9-19.

Mota, J.C.A.; Alves, C.V.O.; Freire, A.G.; Assis Júnior, R.N. 2014. Uni and multivariate analyses of soil physical quality indicators of a Cambisol from Apodi Plateau - CE, Brazil. Soil and Tillage Research 140: 66-73.

Mueller, L.; Shepherd, G.; Schindler, U.; Ball, B.C.; Munkholm L.J.; Hennings, V.; Smolentseva, E.; Rukhovic, O.; Lukin, S.; Hui, C. 2013. Evaluation of soil structure in the framework of an overall soil quality rating. Soil and Tillage Research 127: 74-84.

Mukherjee, A.; Lal, R. 2014. Comparison of soil quality index using three methods. PloS One 9: e105981.

Nakajima, T.; Lal, R.; Jiang, S. 2015. Soil quality index of a Crosby silt loam in central Ohio. Soil and Tillage Research 146: 323-328.

Natural Resources Conservation Service [NRCS]. 2010. Keys to Soil Taxonomy. 11ed. United States Department of Agriculture, Washington, DC, USA.
Obade, V.P.; Lal, R. 2016. A standardized soil quality index for diverse field conditions. Science of the Total Environment 541: 424-434.

Palmeira, P.R.T.; Pauletto, E.A.; Teixeira, C.F.A.; Gomes, A.S.; Silva, J.B. 1999. Soil aggregation of an Albaqualf submitted to different soil tillage systems. Revista Brasileira de Ciência do Solo 23: 189195 (in Portuguese, with abstract in English).

Parfitt, J.M.B.; Timm, L.C.; Reichardt, K.; Pauletto, E.A. 2014. Impacts of land leveling on lowland soil physical properties. Revista Brasileira de Ciência do Solo 38: 315-326.

Paz-Kagan, T.; Shachak, M.; Zaady, E.; Karnieli, A. 2014. A spectral soil quality index (SSQI) for characterizing soil function in areas of changed land use. Geoderma 171-184.

Raiesi, F.; Kabiri, V. 2016. Identification of soil quality indicators for assessing the effect of different tillage practices through a soil quality index in a semi-arid environment. Ecological Indicators 71: 198-207.

Reichert, J.M.; Rosa, V.T.; Vogelmann, E.S.; Rosa, D.P.; Hornd, R.; Reinert, D.J.; Sattlere, A.; Denardin, J.E. 2016. Conceptual framework for capacity and intensity physical soil properties affected by short and long-term (14 years) continuous no-tillage and controlled traffic. Soil and Tillage Research 158: 123-136.

Reis, D.A.; Lima, C.L.R.; Bamberg, A.L. 2016. Physical quality and organic matter fractions of an Alfisol under no-tillage. Pesquisa Agropecuária Brasileira 51: 1623-1632 (in Portuguese, with abstract in English).

Rojas, J.M.; Prause, J.; Sanzano, G.A.; Arce, O.E.A.; Sánchez, M.C. 2016. Soil quality indicators selection by mixed models and multivariate techniques in deforested areas for agricultural use in NW of Chaco, Argentina. Soil and Tillage Research 155: 250262.

Rousseau, L.; Fonte, S.J.; Téllez, O.; Van der Hoek, R.; Lavelle, P. 2013. Soil macrofauna as indicators of soil quality and land use impacts in smallholder agroecosystems of western Nicaragua. Ecological Indicators 27: 71-82.

Thomazini, A.; Mendonça, E.S.; Cardoso, I.M.; Garbin, M.L. 2015. SOC dynamics and soil quality index of agroforestry systems in the Atlantic rainforest of Brazil. Geoderma Regional 5: 15-24.

Van Lier, Q. de J. 2014. Revisiting the S-index for soil physical quality and its use in Brazil. Revista Brasileira de Ciência do Solo 38: 1-10.

Yao, R.; Yang, J.; Gao, P.; Zhang, J.; Jin, W. 2013. Determining minimum data set for soil quality assessment of typical saltaffected farmland in the coastal reclamation area. Soil and Tillage Research 128: 137-148.

Yoder, R.E. 1936. A direct method of aggregate analysis of soil and a study of the physical nature of erosion losses. Journal of American Society of Agronomy 28: 337-351.

Zhang, G.; Bai, J.; Xi, M.; Zhao, Q.; Lu, Q.; Jia, J. 2016. Soil quality assessment of coastal wetlands in the Yellow River Delta of China based on the minimum data set. Ecological Indicators 66: 458-466.

Zornoza, R.; Acosta, J.A.; Bastida, F.; Domínguez, S.G.; Toledo, D.M.; Faz, A. 2015. Identification of sensitive indicators to assess the interrelationship between soil quality, management practices and human health. Soil 1: 173-185. 